\title{
Bird Diversity on Tanimbar Islands with Special Reference to the Tanimbar Corella (Cacatua goffiniana)
}

\author{
Tri Haryoko ${ }^{1,2^{*}}$, Mark O'Hara ${ }^{3}$, Berenika Mioduszewska ${ }^{3}$, \\ Mohammad Irham ${ }^{2}$, Dewi Malia Prawiradilaga ${ }^{2}$, Hari Sutrisno ${ }^{2}$, \\ Lilik Budi Prasetyo ${ }^{4}$, Ani Mardiastuti ${ }^{4 *}$
}

\author{
${ }^{1}$ Program of Tropical Biodiversity Conservation, Faculty of Forestry and Environment, IPB University Bogor, \\ West Java, Indonesia. \\ ${ }^{2}$ Museum Zoologicum Bogoriense, Research Center for Biology, Indonesian Institute of Sciences. Jl. Raya \\ Jakarta Bogor Km 46, Cibinong, Bogor, West Java, Indonesia \\ ${ }^{3}$ Messerli Research Institute, University of Veterinary Medicine Vienna, Medical University Vienna, University \\ of Vienna, Veterinaerplatz 1, 1210 Vienna, Austria \\ ${ }^{4}$ Department of Forest Resources Conservation and Ecotourism, Faculty of Forestry and Environment, IPB \\ University, Bogor, West Java, Indonesia \\ ${ }^{*}$ Corresponding author. E-mail: aniipb@indo.net.id; tri_007mzb@apps.ipb.ac.id \\ All authors contributed equally to this work
}

\begin{abstract}
The Tanimbar Islands located in the Wallacea region have particularly important ornithological values due to high level of endemism. Avian researchers have carried out expeditions to Tanimbar since long time ago starting with Forbes in 1882. An iconic bird of the Tanimbar Islands is the endemic Tanimbar corella (Cacatua goffiniana). This species is considered near threatened by the IUCN, listed in CITES Appendix I, and is protected under Indonesian law. The objectives of the study were to assess bird diversity, habitat use, and association between $C$. goffiniana and other bird species on the Tanimbar Islands. Data were collected between 2015 and 2019 on Yamdena, Larat, Selaru, and Vaimar Island of Kepulauan Tanimbar Regency, Maluku Province. Direct observation and mist-netting technique were conducted to assess the bird diversity. The habitat use was mapped using ArcGIS 10.5. Descriptive analysis was used to reveal associations between Tanimbar corella and other species. The diversity assessment recorded 142 species in which there were 13 new records for this location. The Tanimbar Islands offer several types of habitats, namely forests, open land, swamps, mangroves, and coastal areas. Associations between $C$. goffiniana and other birds were recorded with regards to competition and sharing of food resources and nesting sites. C. goffiniana competes with Eclectus roratus for nesting opportunities, and they have an overlapping diet. In addition, $C$. goffiniana often shares nesting sites with Eos reticulata or Aplonis crassa by using the same trees, and sometimes even the same hollows for nesting. During the observation in AugustNovember 2015, several species were found entering breeding period, namely $C$. goffiniana, $E$. roratus, E. reticulata, A. crassa, Philemon mollucensis, Chalcophaps indica, Rhipidura rufifrons, and Lonchura quinticolor. Deforestation resulting in loss of nest and foraging trees pose the major threat to the wild bird population, especially $C$. goffiniana. By promoting $C$. goffiniana as an umbrella species we expect to conserve the biodiversity in the region.
\end{abstract}

Keywords: bird diversity, Cacatua goffiniana, endemism, habitat, Tanimbar

\section{INTRODUCTION}

The wallacea region is one of the most attractive zoogeographic areas in the world that It is located between the Oriental region to the west and the Australo-Papua region to the east. It is a transition zone for Oriental and Australo-Papuan avifaunal elements divided into three sub-regions, namely Sulawesi, Lesser Sunda, and Moluccas [1] [2]. This area rich in biodiversity due to the large number of species and endemism [3], especially in the bird species [2]. A total of 336 species are recorded as 
endemic in the Wallacea region, including 150 species from Sulawesi, 126 species from Lesser Sunda and 90 Mollucan species [4].

The Tanimbar Islands are one of the Wallacea regions designated as an "Important Birds Area" [5]. It is a relatively small archipelago featuring 65 islands $(10,102.92 \mathrm{~km} 2)$ in the Tanimbar Islands Regency, Maluku Province [6] approx. $500 \mathrm{~km}$ east of Timor and $500 \mathrm{~km}$ north of Australia [7]. The Tanimbar Islands are home to hundreds of species of birds with high level of endemism. The first recorded ornithological expedition to Tanimbar was conducted by Forbes in 1882 to the islands of Yamdena, Moeloe and Kirimoen. The first list of bird species on Tanimbar Island was compiled by Bishop \& Brickle (1998) from data provided by various experts and expeditions from between 1882 and 1997.

The Tanimbar Islands are recognized by Birdlife International as an important center of bird endemism [8]. One of the iconic endemic birds on Tanimbar Islands is Cacatua goffiniana (Tanimbar corella; alternative common name: Goffin's cockatoo). The Indonesian government has protected C. goffiniana by the Act of the Republic of Indonesia No. 5 of 1990. Internationally, the Convention on International Trade in Endangered Species of Wild Fauna and Flora (CITES) listed $C$. goffiniana in the Appendix I in 1992 [9]. The International Union for Conservation of Nature (IUCN) Red List categorized C. goffiniana as a near threatened which may be onsidered threatened with extinction in the near future, although it does not currently qualify for the threatened status [10].

So far, no update of the checklist of birds on Tanimbar Islands was conducted since the first publication by Bishop \& Brickle (1998). Additionally, the importance of $C$. goffiniana as an endemic bird on Tanimbar Islands requires, further research. The objectives of this study were to assess bird diversity, habitat use, and association between $C$. goffiniana and other bird species on the Tanimbar Islands. $C$. goffiniana was used as an example to describe the unique diversity of birds in the Tanimbar Islands.

\section{MATERIALS AND METHOD}

Data were collected between 2015 and 2019 on Yamdena, Larat, Selaru, and Vaimar Islands of the Tanimbar Archipelago. Data was obtained through direct observations and mist-netting. Observations were conducted at 06.00-10.00 and 15.00-18.00. Mist-netting was only used on Yamdena Island, in Lorulun (27.09 27- 10.10., 2015; 15.04- 02.05., 2018) and Tutukembong (13.11-18.11., 2015) villages. Observations were carrymade in the morning at 06.00-10.00 and 15.00-18.00. The type and location of the encounter birds were recorded and mapped using ArcGIS 10.5 software. The encountered habitats were split into five categories, namely forests, open land, swamps, mangroves, and coastal areas. Forest category consisted of primary and secondary monsoon forests. Open land habitat consisted of settlements, grasslands, agricultural land, and cleared area. Swamps consisted of all water bodies such as swamps, ponds, and rivers. Mangroves were specific vegetation near rivers and coastal area. The coastal habitat consisted of mudflats, beaches, and sea.

Descriptive analysis was used to reveal associations between C.goffiniana and other species. The parameters used to determine which bird species entered the breeding period were observed nest material collection and nest building behaviors as well as encountered the activity of finding eggs and chicks in nest cavities.

\section{RESULTS AND DISCUSSION}

\subsection{Avifauna of Tanimbar Islands}

Based on our observations and the data reported by Bishop and Brickle (1998), the total recorded avifauna on Tanimbar Islands amounted 142 species of 16 orders and 54 families (see Fig. 1). The conservation status of avifauna on Tanimbar Islands is listed in Table 1. A complete list of avifauna species on the Tanimbar Islands is listed in the appendix 1. We observed 92 species, adding 13 previously unreported species. The number of species may still increase if more intensive research is carried out on the whole archipelago and in all habitat types on the Tanimbar Islands. 


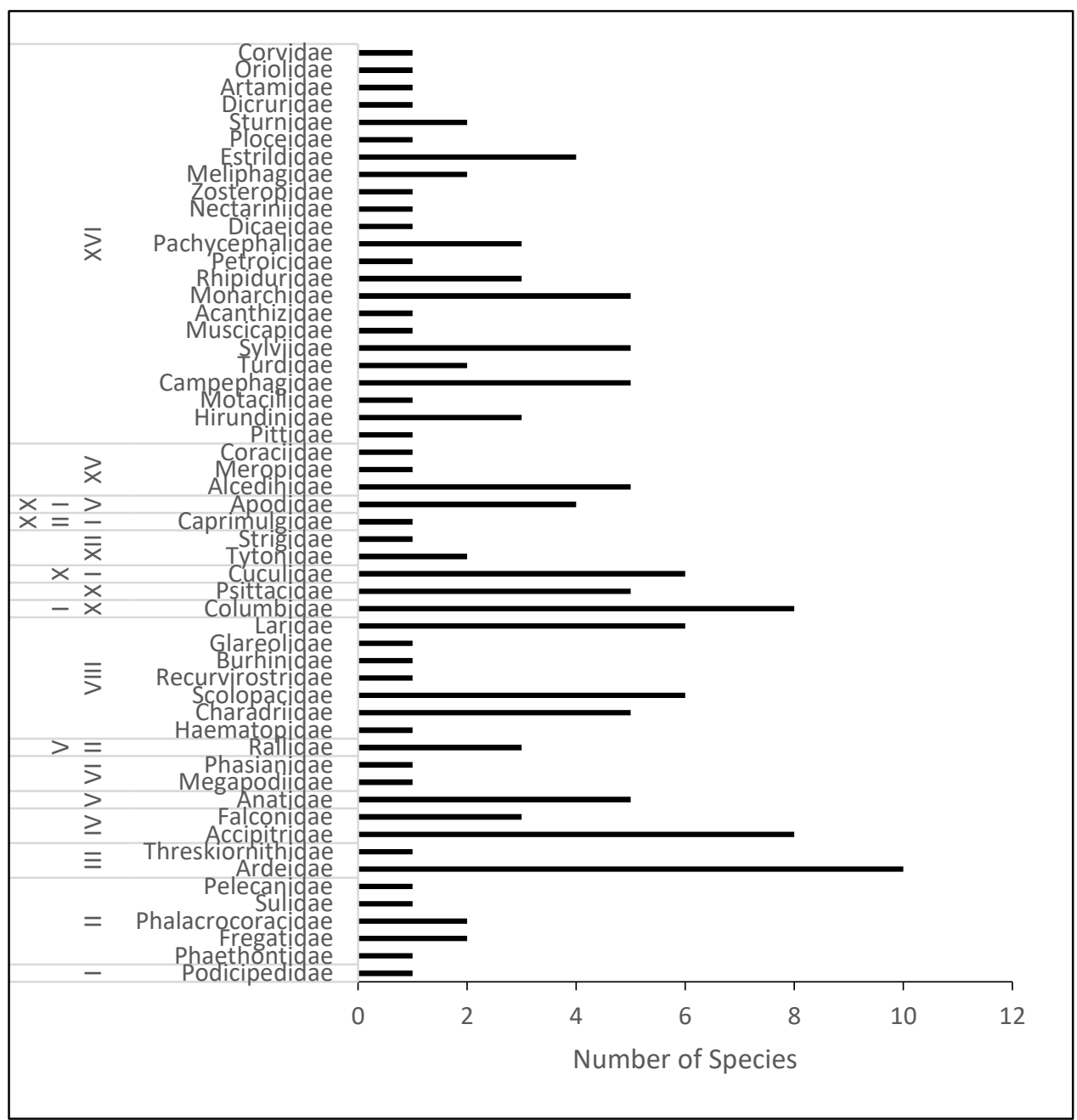

Figure 1 Composition of avifauna on the Tanimbar Islands

The avifauna list was recorded from a few islands of the Tanimbar Archipelgo. Bishop \& Brickle (1998) collected bird data from Yamdena, Larat, Selaru, Lutu, Molu, and Kirimoen Islands, while this study added observations from Yamdena, Selaru, Larat and Vaimar Islands (see Fig. 3). The avifauna of the Tanimbar Islands are dominated by the order of Passeriformes and the families Ardeidae, Columbidae, and Accipitridae. Encountered species used various open land habitats such as coast, agricultural land, and forest edge, which allowed for easy observation and and identification.

Table 1. The conservation status of avifauna on Tanimbar Islands

\begin{tabular}{|l|c|}
\hline Status & Number of Species \\
\hline Migratory & 24 \\
\hline Endemic Country & 26 \\
\hline Endemic Tanimbar & 9 \\
\hline Endemic Subspecies & 11 \\
\hline Protected & 34 \\
\hline Appendix I CITES & 1 \\
\hline Appendix II CITES & 6 \\
\hline IUCN Near Threatened & 15 \\
\hline
\end{tabular}


Tanimbar Islands are an important area for the various bird species that need conservation attention because migrant, endemism, protected, and status of their population (see Table 1). There are 24 species of migratory birds, 34 species protected by Indonesian law, 15 species categorized as near threatened by IUCN, 1 species listed in Appendix I, and 6 species bird listed in Appendix II CITES. The Tanimbar Islands are also home to 26 endemic species and 11 endemic sub-species. Therefore,
Birdlife International has recognized the Tanimbar Islands as a center of bird endemism. It is included in the Banda Sea Archipelago which was designated as Endemic Bird Area (EBA 165) [8]. During this study, a total of 9 endemic species were observed, namely Megapodius tenimbarensis, Eos reticulata, Cacatua goffiniana, Zoothera schistacea, Zoothera machiki, Cettia carolinae, Rhipidura opistherythra, Microeca hemixantha and Aplonis crassa.

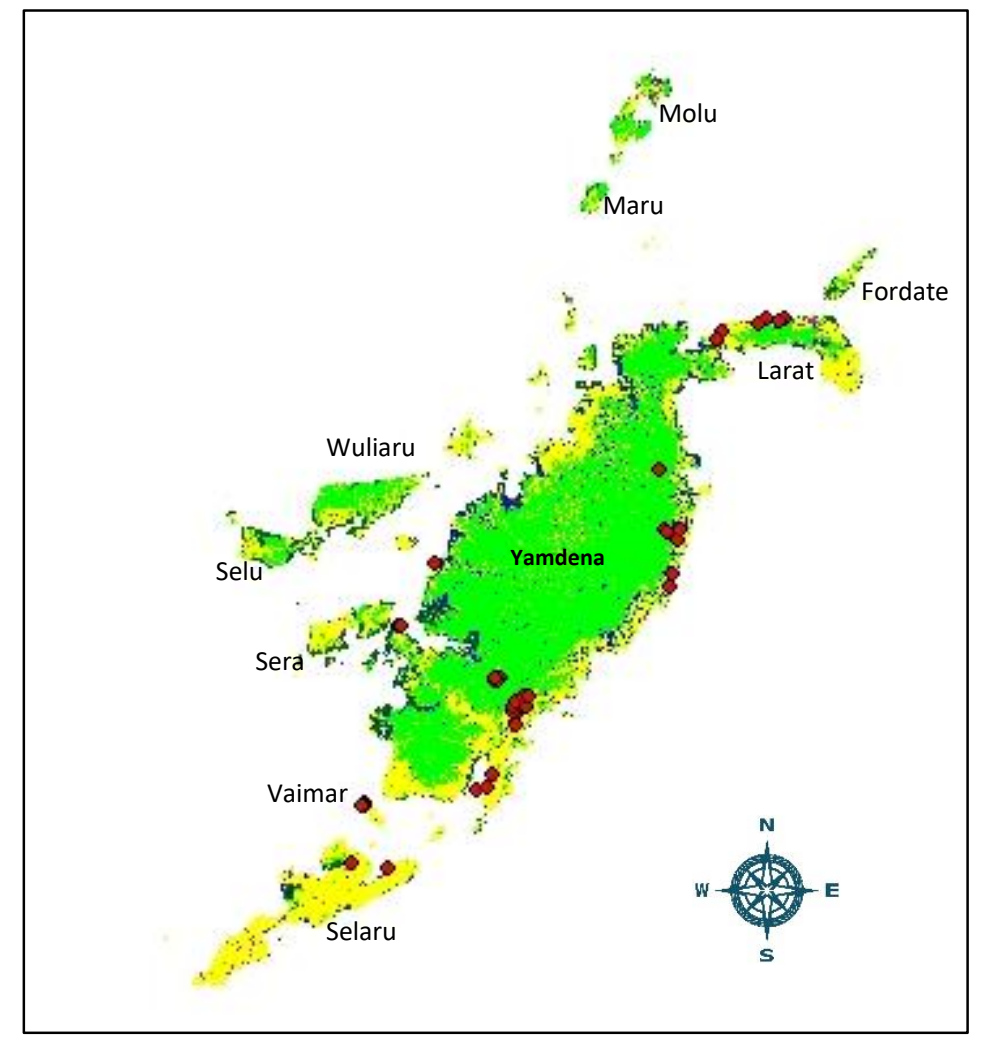

Figure 2 Distribution of bird species observed on Tanimbar Islands in 2015 and 2019

The Tanimbar Islands are biogeographically part of South Maluku based on diversity and endemism of bird species [11] [12]. In terms of the geological history, the Tanimbar Islands were formed from sedimentary, metamorphic, and a few igneous rocks since the Quaternary age, they have the same geological origin with southern Maluku [1]. Together with Timor, Kai Besar, Buru, and Seram Islands are part of the non-volcanic outer Banda Arc. The Tanimbar Islands differ in geological origin from Solor, Alor, Wetar and Banda Islands, because they originate from the inner volcanic Banda Arc [13]. The outer Banda Arc were neither joined, nor was there any connection between the islands of different geological origin [14].

This study was focused on the eastern part of the Yamdena Island, which feature forests and open land consisting of settlements, plantations, agricultural fields, and coastal area. Only a few locations were observed in the western part of the Yamdena Island such as Makatian and Batu Putih villages which featured mangrove and coastal areas. Based on the avifauna distribution (see Fig.2), most of the forest habitats have so far not been intensively investigated in terms of their bird population. Obtaining data about additional species and potentially even discovering new bird species poses a logistic challenge due to the remoteness of suitable candidate locations and lack of infrastructure. Likewise, many islands of Tanimbar Archipelago have not been thoroughly explored yet with regard to species presence and distribution. 


\subsection{Habitat use of avifauna on Tanimbar Islands}

Structurally, Tanimbar Islands are like western Timor. Post-pleiocene deformation was marked by a thrust separating the western islands of the Tanimbar Archipelago from the main island of Yamdena [7]. Therefore, Tanimbar Islands provide various types of habitats for their avifauna. The composition of bird species based on the habitat used is shown in Table 1.

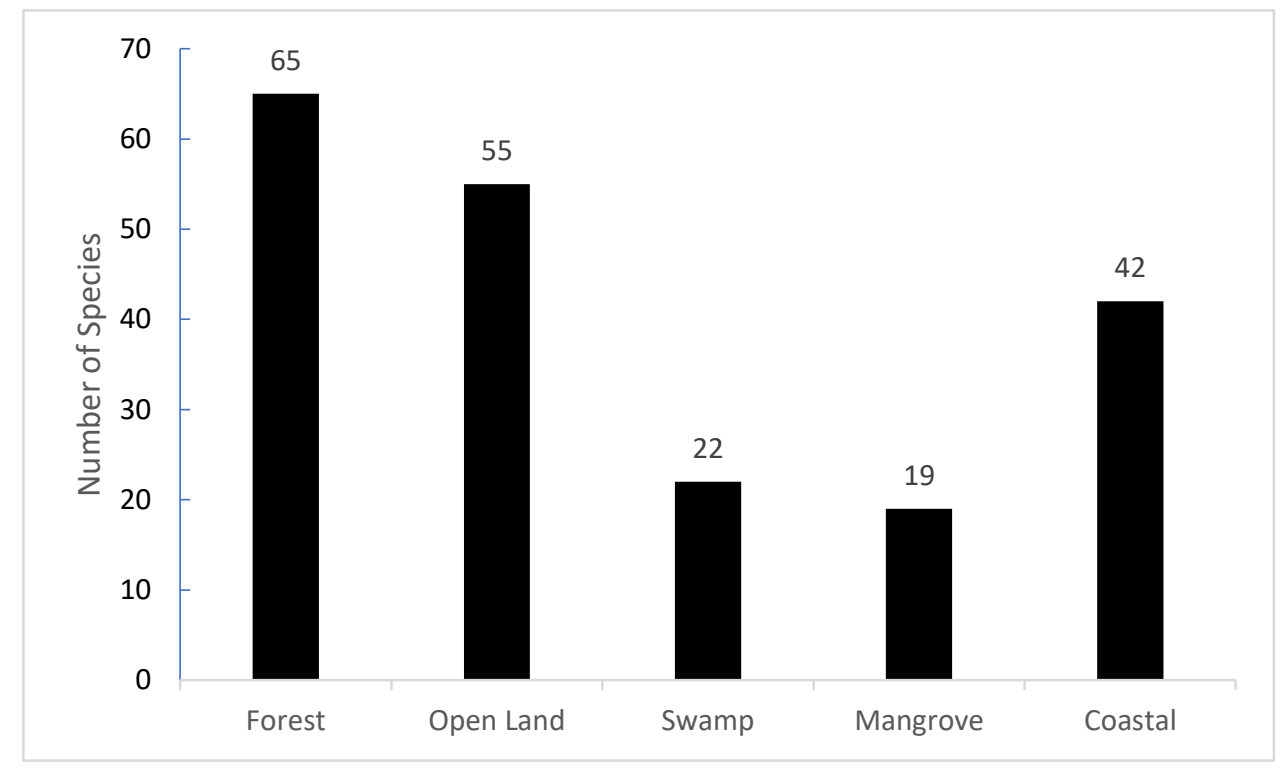

Figure 3 Number species of bird used each habitat on Tanimbar Islands

Avifauna in the Tanimbar Islands occupies five types of habitats, namely forests, open land, coastal, swamps, and mangroves with varied bird species compositions (see Fig.3). Forest habitats in the Tanimbar Islands were categorized into dry deciduous forest and moist deciduous forest [15]. However, based on their utilization, forests were categorized into four types of forest, including protected forest, limited production forest, convertible production forest, and Nature Reserve Forest [6]. Based on canopy cover, the forest on the Tanimbar Islands is divided into two types, namely semi-evergreen (characterized by multi-storey canopy and young trees) and monsoon forests with discontinuous canopy of tall trees at more than $30 \mathrm{~m}$ [16]. Forests are important habitats for many bird species as a place to live, where they find food and nest tree. Large trees are indispensable for birds as nesting sites, providing fruit and shelter from predators. Several species of birds that require large trees with suitable nest cavities include $C$. goffiniana, E. roratus, C. onru, D. concinna and E.reticulata.

The open land habitat on the Tanimbar Islands is also an important habitat for 55 bird species. This habitat consists of agricultural land, grass land, settlement areas, and cleared areas. Corn, rice, papaya, peanuts, and bean cultivation provide ample foraging opportunities for granivorous and frugivorous bird species. Several types of birds also often use two or more types of habitat. C. goffiniana is a common bird species dwelling in forest and agricultural land [15][17].

Coastal areas are important habitats, especially for water and migratory birds, which use the coast, mudflats, and seas for resting and foraging. The habitat provides various food sources, such as crustacean or fish. A total of 24 species of migratory birds from Australia and the Palearctic visit Tanimbar Islands each year. We observed these birds around Makatian and Batu Putih villages, the capital town of Saumlaki, as well as Selaru, Larat and Vaimar Islands. Tanimbar Islands do not have many swamp habitats consisting of water bodies and ponds. There is only one large standing water body near the Mathilda Batlayeri airport, the other being a river which runs mostly in the western part of Yamdena Island. The present of these water bodies is important for the resident and migrant bird species. We recorded 22 water and migratory bird species in the swamp habitat. The mangrove habitat, located around the coast and the river, was not widely observed in this study and only 19 species could be identified.

\subsection{Association between C. goffiniana and other birds on Tanimbar Islands}

Cacactua goffiniana is the only cockatoo species endemic to Tanimbar Islands. This bird 
inhabits predominantly the forest and open land habitats [18]. It is relatively conspicuous due to its distinctive call and largely white plumage. The presence of this bird in several habitat types also promotes interactions with other avifauna. Our observations on Yamdena and Selaru Island observed two associations between C. goffiniana and other bird species, namely competition and sharing of food sources, nesting, and roosting sites. Observations carried out in open land habitats in an agricultural field found that $C$. goffiniana and $E$. roratus used the same banana tree as a feeding location, although at different collection times. They were observed feed on the same food sources [17]. However, these two species compete for trees that are used for nesting and roosting. Each species defended its tree in a loud manner and tried repelling or attack other species approaching the tree. Competition to use the White Cheesewood tree (Alstonia scholaris) for roosting also occurred with Corvus orru on Selaru Island, however C. goffiniana allowed was tolerant of Ducula concinna perching on the same tree.

Sharing associations were observed between C. goffiniana, E. reticulata, A. crassa, and $D$. concinna. The associations between these four species were observed on Yamdena Island in using the same tree for nesting and roosting. Several tree species were used and selected by $C$. goffiniana for nesting trees including Iron Trees (Intsia bijuga), New Guinea Rosewood (Pterocarpus indicus) and Blackboard Tree / White Cheesewood (Alstonia scholaris) [17]. In this study, we often observed that while these bird species can establish a nest on the same tree, they might use different parts. The existence of competition and sharing associations was also suggested, as several species enter the same breeding period. During the observation in AugustNovember 2015, several species were found entering breeding period, namely C. goffiniana, E. roratus, $E$. reticulata, A. crassa, Philemon mollucensis, Chalcophaps indica, Rhipidura rufifrons, and Lonchura quinticolor. During that period, breeding behaviours were encountered, such as looking for nest material and building a nest, as well as eggs and chicks were encountered in nest cavities. Therefore, it suggests that several species will interact because of the same needs.

\subsection{Threat of avifauna diversity on Tanimbar Islands}

Avifauna and biodiversity on Tanimbar Islands face the threat of loss or decline in their population. Several activities were encountered during the research that could threaten biodiversity, such as cutting trees and burning forests for clearing of agricultural land as well as hunting birds and other animals for food. Bird populations are considered as decreasing due to habitat degradation and trapping [10].

\section{CONCLUSION}

Tanimbar Islands have high biodiversity including birds, due to the diversity of habitat types. The presence of many endemic birds (species and subspecies) as well as, migratory and protected species, listed in the CITES Appendix signify the importance of this area for conservation efforts to prevent extinction and population decline. Deforestation resulting in loss of nest and foraging trees is the major threat to the wild bird population, especially $C$. goffiniana. By promoting $C$. goffiniana as an umbrella species we expect to conserve the biodiversity in the region.

\section{ACKNOWLEDGMENT}

We thank the Indonesian Institute of Sciences (LIPI), Ministry of Environment and Forestry of the Republic of Indonesia who granted the permit to conduct this research. The study was funded by LIPI, Austrian Science Fund (FWF), Messerli Research Institute, Deputy of Research and Development the Ministry of Research and Technology-National Research and Innovation in accordance with the Agreement on Assignment of Research Implementation in 2020 number: 1/E1/KP.PTNBH/2020. We would like to express our gratitude the members of the Hurlatu Clan of the Lorulun village for their invaluable help during fieldwork.

\section{REFERENCES}

[1] K.A. Monk, Y. De Fretes, and G.R. Lilley. 'The Ecology of Nusa Tenggara and Maluku', Periplus Editions, Singapore, 1997.

[2] B.J. Coates, and K.D. Bishop. 'A Guide to the Birds of Wallacea: Sulawesi, the Moluccas and Lesser Sunda Islands, Indonesia', Dove Publications, Australia, 1997.

[3] K. Lohman, M.D. Bruyn, T. Page, K.von Rintelen, R. Hall, P.K.L. Ng, H.T. Shih, G.R. Carvalho, and T. von Rintelen, 'Biogeography of the Indo-Australian Archipelago'. AREES., vol 42, pp. 205- 
226, 2011. DOI: 10.1146/annurev-ecolsys102710-145001

[4] D. M. Prawiradilaga, 'Keanekaragaman dan Strategi Konservasi Burung Endemik Indonesia', LIPI Press, Jakarta, 2019.

[5] BirdLife International, 'Important Bird Areas factsheet: Tanimbar Tengah'. Accessed: Sept. 07, 2020. [Online]. Available: http://www.birdlife.org.

[6] Pemerintah Kabupaten Maluku Tenggara Barat, 'Rencana Tata Ruang Wilayah (RTRW) Kabupaten Maluku Tenggara Barat 2012-2032'. Pemerintah Daerah Kabupaten Maluku Tenggara Barat, Saumlaki, 2012.

[7] T.R. Charlton, M.M.M. De Smet, H. Samodra, and S.J. Kaye, 'The Stratigraphic and Structural Evolution of The Tanimbar Islands, Eastern Indonesia'. SAES., vol 6 no.3, pp. 343-358. 1991.

[8] K.D. Bishop, and N.W. Brickle. 'An Annotated Checklist of The Birds of The Tanimbar Islands'. Kukila., vol. 10, pp. 115-150, 1998.

[9] Convention on International Trade in Endangered Species of Wild Fauna and Flora. 'Checklist of CITES species'. Accessed:Jul.31, 2019. [Online]. Available: https://www.cites.org/eng/app/index.php.

[10] BirdLife International. 'Cacatua goffiniana. The IUCN Red List of Threatened Species'. Accessed:Jul.31, 2019. [Online]. Available: e.T22684800A131915554.

[11] C.M.N. White, and M.D. Bruce, 'The Birds of Wallacea (Sulawesi, The Moluccas \& Lesser Sunda Islands, Indonesia) Check-list No. 7'. An Annoted Checklist. B.O.U., London, 1986.
[12] J.A.Eaton, B. van Balen, N.W.Brickle, and F.E.Rheindt, 'Birds of Indonesian Archipelago.Greater Sunda and Wallacea'. Lynx Edicions, Barcelona, 2016.

[13] R. Hall, 'Cenozoic Geological and Plate Tectonic Evolution of SE Asia and the SW Pacific:Computer-Based Reconstructions, Model and Animations'. JAES., vol. 20, pp. 353-431, 2002.

[14] M.G. Audley-Charles, 'Timor-Tanimbar Trough: The Foreland Basin of The Evolving Banda Orogen'. SPIAS., Vol.8, pp. 91-102, 1986.

[15] P. Jepson, N.Brickle, and Y. Cahyadin. 'The Conservation Status of Tanimbar Corella and Blue-Streaked Lory on The Tanimbar Islands, Indonesia: Results of A Rapid Contextual Survey'. Oryx., vol. 35 no.3, pp. 224-233, 2001.

[16] Y.P. Cahyadin, P. Jepson, and B.I. Manoppo,'The Status of Cacatua goffini and Eos reticulata on the Tanimbar Islands'. Report No. 1, PHPA/BirdLife International Indonesia Programme, Bogor, 1994.

[17] B. Mioduszewska, M. O’Hara, T. Haryoko, A.M.I. Auersperg, L. Huber, and D.M. Prawiradilaga. 'Notes On Ecology of Wild Goffin's Cockatoo in The Late Dry Season With Emphasis on Feeding Ecology'. Treubia., vol. 45, pp. 85-102, 2018.

[18] M. O’Hara, B. Mioduszewska, T. Haryoko, D. M. Prawiradilaga, L. Huber, A. Auersperg, 'Extraction without tooling around-The first comprehensive description of the foraging- and socio-ecology of wild Goffin's cockatoos (Cacatua goffiniana)'. Behaviour., Vol. 156, pp. 661-690, 2019. DOI:10.1163/1568539X-00003523. 


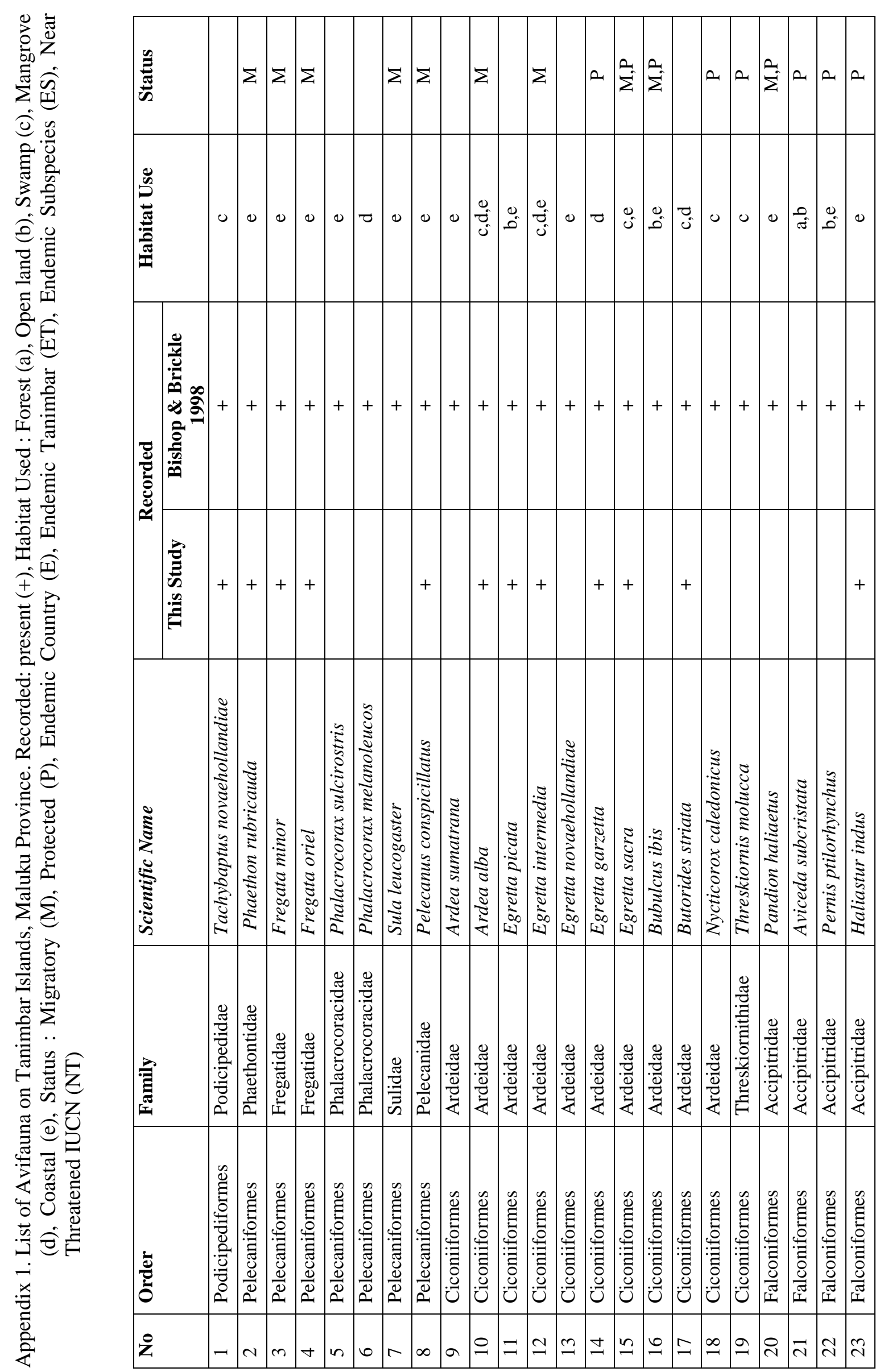



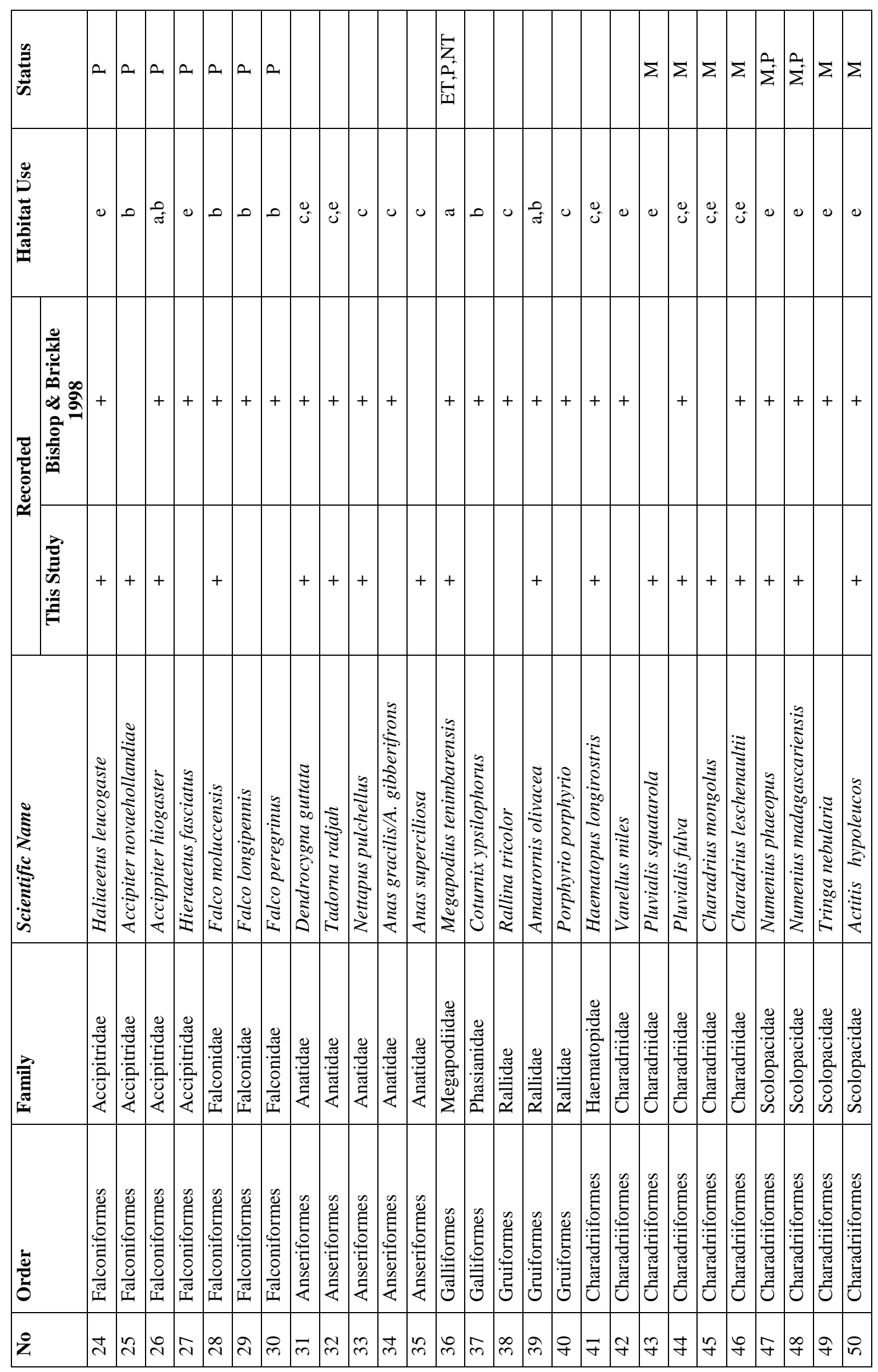

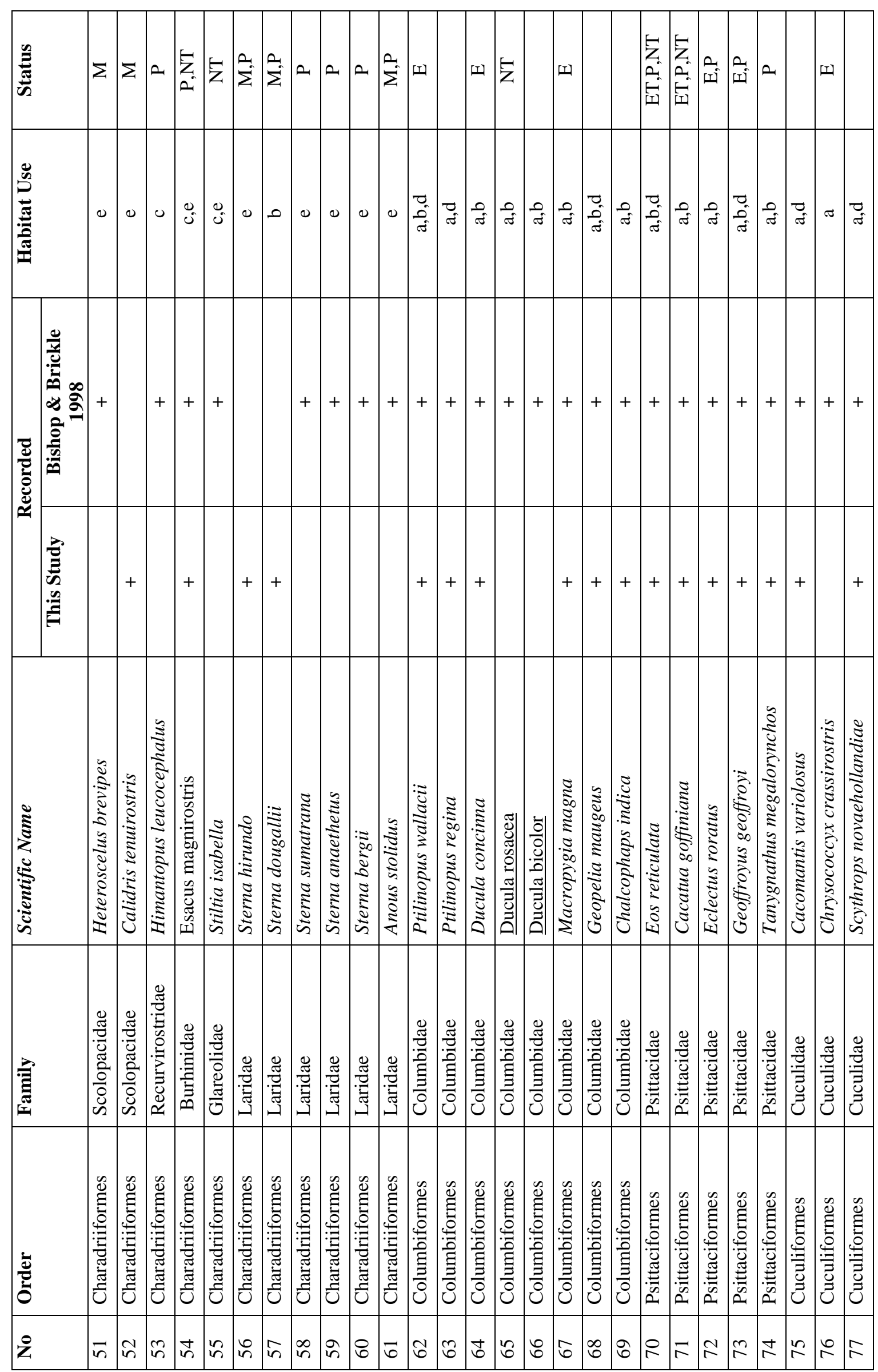

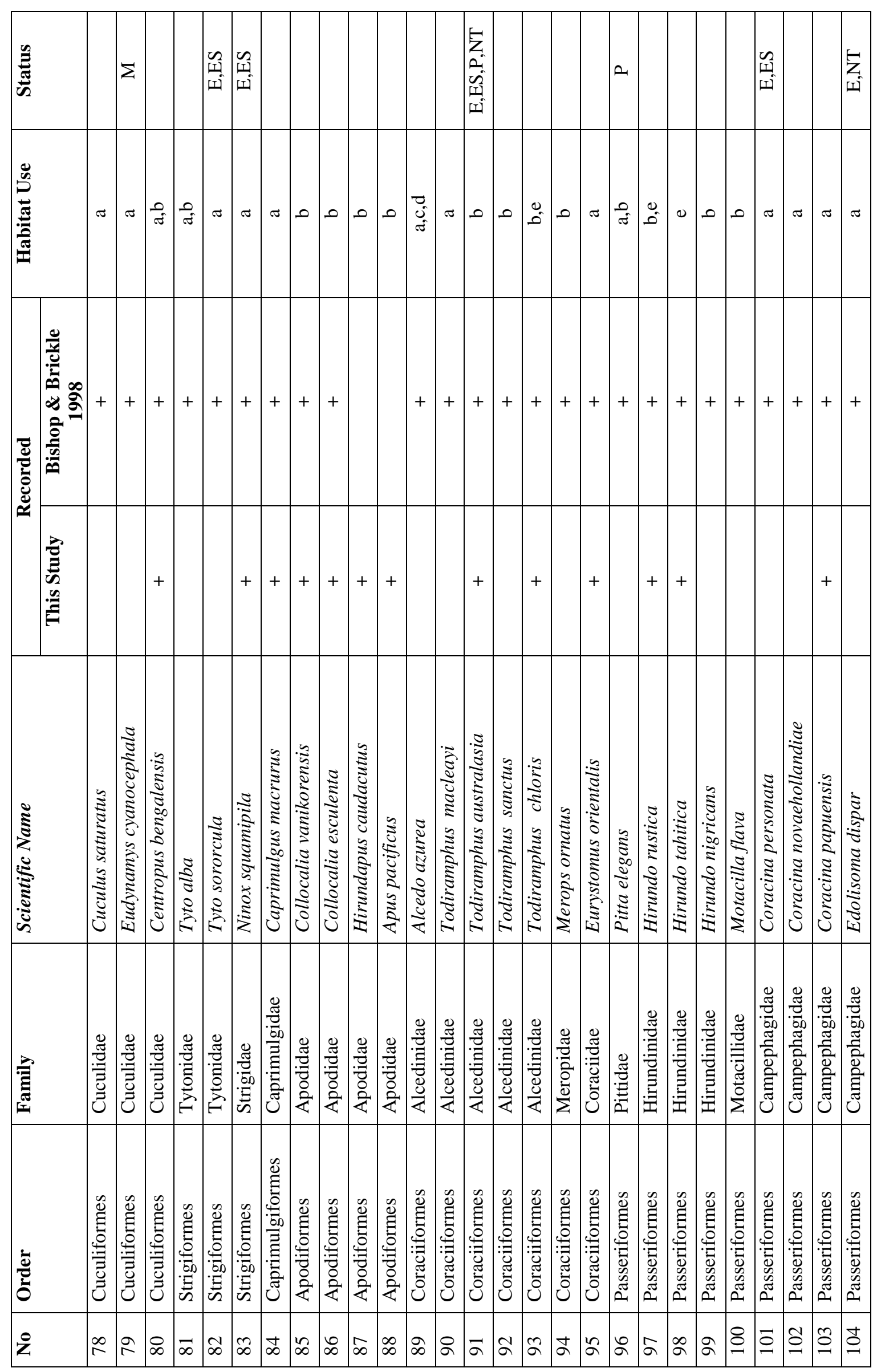

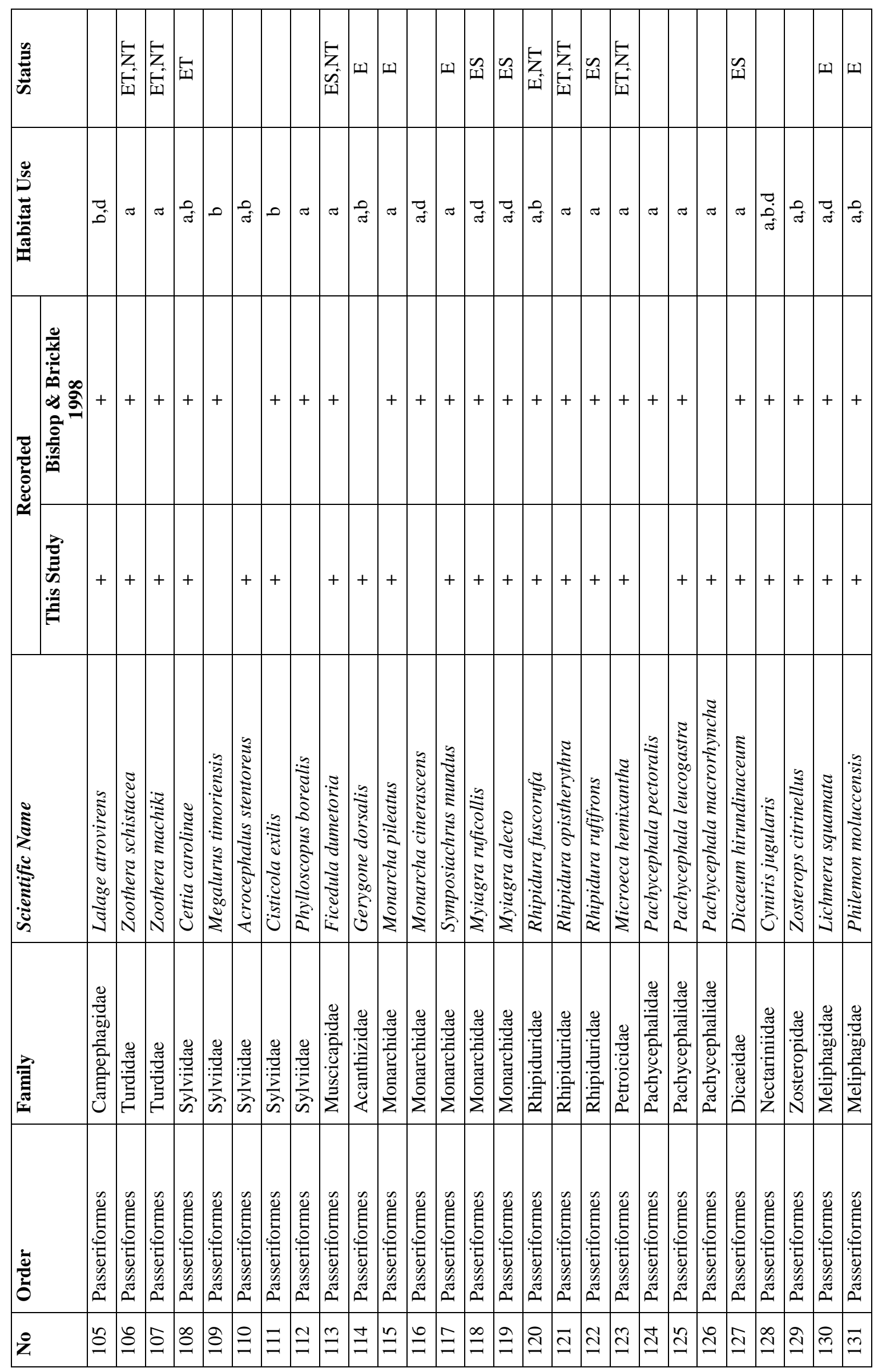


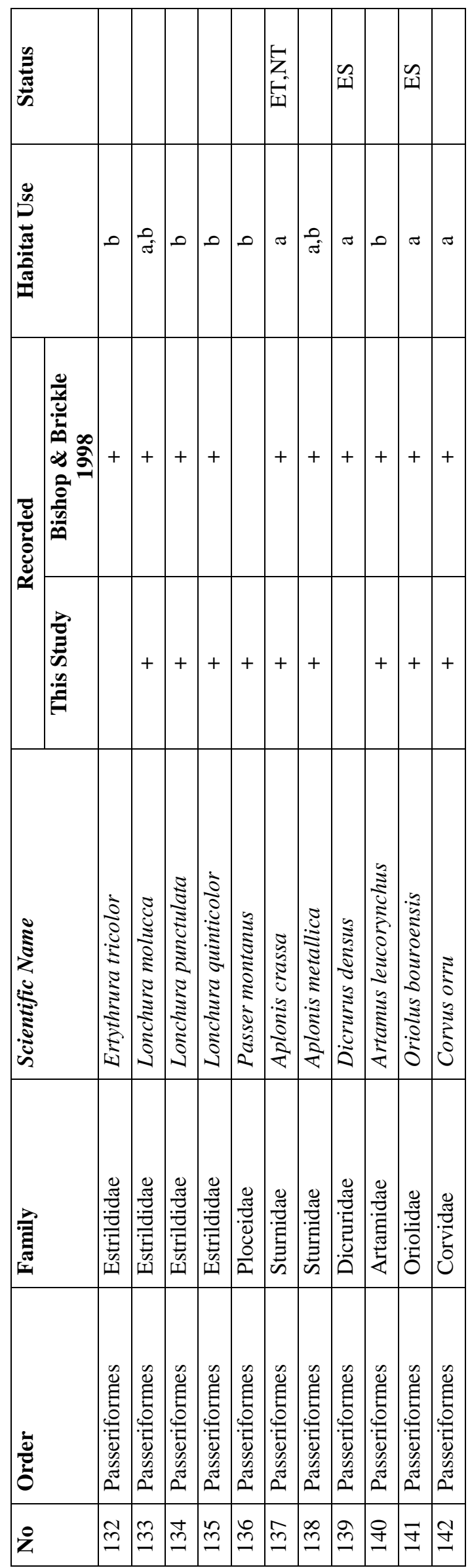

